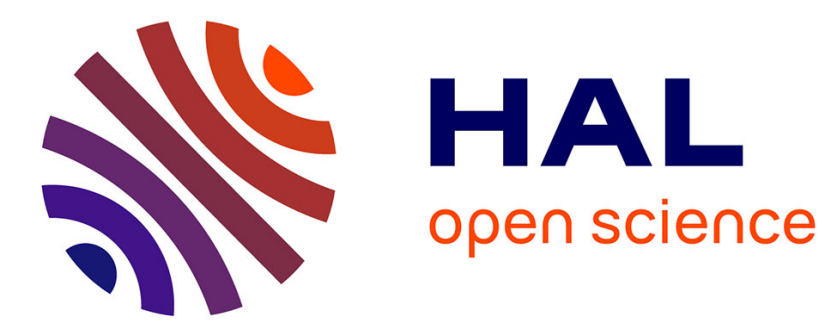

\title{
Impact Tensile Strength and Fracture of Concrete
}

\author{
M. Diamaruya, H. Kobayashi, T. Nonaka
}

\section{To cite this version:}

M. Diamaruya, H. Kobayashi, T. Nonaka. Impact Tensile Strength and Fracture of Concrete. Journal de Physique IV Proceedings, 1997, 07 (C3), pp.C3-253-C3-258. 10.1051/jp4:1997345 . jpa-00255502

\section{HAL Id: jpa-00255502 https://hal.science/jpa-00255502}

Submitted on 1 Jan 1997

HAL is a multi-disciplinary open access archive for the deposit and dissemination of scientific research documents, whether they are published or not. The documents may come from teaching and research institutions in France or abroad, or from public or private research centers.
L'archive ouverte pluridisciplinaire HAL, est destinée au dépôt et à la diffusion de documents scientifiques de niveau recherche, publiés ou non, émanant des établissements d'enseignement et de recherche français ou étrangers, des laboratoires publics ou privés. 


\title{
Impact Tensile Strength and Fracture of Concrete
}

\author{
M. Diamaruya, H. Kobayashi and T. Nonaka*
}

Department of Mechanical Systems Engineering, Muroran Institute Institute of Technology, 27-1 Mizumoto, Muroran, Hokkaido 050, Japan

* Disaster Prevention Research Institute, Kyoto University, Gokasho, Uji City, Kyoto Prefecture 611, Japan

\begin{abstract}
This paper is concerned with a new measuring method for impact tensile strength of brittle materials such as ceramics, concrete and so forth. The method is based on the superposition and concentration of tensile stress waves reflected both from the free ends of a specimen and a striking bar. By making use of the Hopkinsonbar technique. impact tensile experiments on concrete are performed. The statistical analysis of the experimental data obtained in a series of impact tensile break tests is presented and compared with that of static tensile and bending tests. It is found that the tensile strength of concrete is significantly influenced by loading rate.
\end{abstract}

Résumé : L’article traite une nouvelle méthode de mesure pour lả traitement de la résistance à la traction des matériaux fragiles tels que céramique et béton. La méthode est basée sur la superposition et la concentration dues à la rétlexion d'ondes de contrainte de traction entre les extrémités libres de l'échantillon et de l'impacteur. En utilisant la technigue d'Hopkinson, une série d'expériences en traction à l'impact a élé conduite sur du bétun. L'analyse statistique des donnéts obtenues au cours des expériences de rupture en tration à l'impact est présentée el comparée avec celle des essias en traction quasi statique et en flexion. Il a été observé que la résistance à la traction du béton est intluencéte par la vitesse du chargement. d'une façon significative.

\section{INTRODUCTION}

It has long been known that concrete materials have a low tensile strength compared to their compressive strength. Since concrete is inherently weak in tension, it has been used as compressive member material in most structures. However, even though static tensile loads on concrete members are avoided. it is difficult to isolate concrete members from dynamic or impact tensile stresses. The propagation of tensile stress waves in structural members is generated by explosives, impingement of projectiles, earthquakes and so on $[1,2]$. In fact, in the Great Hanshin-Awaji Earthquake in 1995. some uncommon fractures and damages of concrete structures were observed which might have been caused by the propagation of stress waves and/or interference of tensile stress waves [3].

In the general, accurate measurement of tensile strength for brittle or quasi-brittle materials such as ceramics, rocks and concretes is known to be difticult. In particular, a measuring method for tensile strength under impact loadings for such brittle materials has not been established yet. Although many investigations, not only on impact compressive strength of concrete materials, but also their impact tensile strength have been reported, there does not seem to be a standard test method for impact tensile strength of concrete $[4-7]$.

This paper is concerned with a new measuring method for impact tensile strength of brittle materials such as ceramics, concrete and so forth by utilizing the concentration phenomenon of reflected tensile stress waves propagated through the specimen bars [8-10]. The method is based on the superposition and concentration of tensile stress waves reflected both from the free ends of a striking bar and a specimen bar. The impact tensile experiments are conducted by means of the Hopkinson-bar technique. The setup consists of a striking bar, shot out from an air gun, and an input bar which is struck on one end by the striking bar. The other end of the input bar is in tight contact with one end of a concrete specimen bar. The measurement theory and the impact tensile fracture behavior of brittle material specimens are discussed by the simple theory of stress waves propagation in a bar. According to the foregoing measuring method and arrangements, impact tensile strength experiments on concrete are performed. The statistical analysis of the experimental data obtained in a series of imput fracture experiments is presented and compared with that of the static tensile and hending tests. It is found that the impact tensile strength of concrete is significantly influenced by loading rate

Article published online by EDP Sciences and available at http://dx.doi.org/10.1051/jp4:1997345 


\section{CONCRETE SPECIMENS}

\subsection{Specimen Dimensions and Concrete Mix Proportions}

The concrete mix proportions used for this study are shown in Table 1. An ordinary Portland cement with fine and coarse aggregates was employed for the fabrication of concrete specimens. The maximum coarse aggregate size was chosen as $10 \mathrm{~mm}$, considering the dimensions of the concrete specimens. Static tests of direct tension, splitting tension, 3-point bending and compression were carried out to examine the static mechanical properties of the concrete specimen cured for more than 28 days. Two different types of concrete specimens were used in the static tests: cylindrical bar specimens with $50 \mathrm{~mm}$ diameter and 100 mm length for splitting tension and compression tests, and rectangular beam specimens with a thickness of $50 \mathrm{~mm}$, a width of $100 \mathrm{~mm}$ and a length of $530 \mathrm{~mm}$ for direct tension and compression tests.

For the impact tensile strength experiment, cylindrical bar specimens with $50 \mathrm{~mm}$ diameter and $500 \mathrm{~mm}$ length were used.

\subsection{Static Tests}

Static tests of direct tension, splitting tension, 3-point bending and compression are performed for the concrete specimens. The static tests are conducted using an INSTRON (model 5586) material test machine. In the direct tension test at loading rates of $0.05-0.5$ $\mathrm{mm} / \mathrm{min}$, a special specimen holder that was developed in our laboratory is employed in order to eliminate bending effects.

Fig. 1 shows a typical result of direct tension tests, which presents the diagram of direct tension stress-strain and also the relation to bending component. The bending component factor, $\delta$, is given by $\delta=\left(\varepsilon_{\text {max }}-\varepsilon_{\text {min }}\right) / 2 \varepsilon_{\text {ave }}$. Here $\varepsilon_{\text {ave }}$ is the average strain measured at the centre of four sides of the rectangular prismatic specimen. $\varepsilon_{\max }$ and $\varepsilon_{\min }$ are the maximum and minimum strains in the four sides, respectively. Detailed illustrations in regard to other static tests performed are cut short on account of space limitations.

Table 1 Concrete mix proportions by weight.

\begin{tabular}{|ll|}
\hline Water & 1 \\
Portland cement & 1.54 \\
Fine aggregate & 4.7 \\
Coarse aggregate & 2.24 \\
(maximum diameter : $10 \mathrm{~mm}$ ) & \\
\hline
\end{tabular}

Table 2 Mechanical properties of concrete.

\begin{tabular}{|ll|}
\hline Elastic modulus E & $17.5 \mathrm{GPa}$ \\
Mass density $\rho$ & $2300 \mathrm{~kg} / \mathrm{m}^{3}$ \\
Poisson's ratio & 0.18 \\
Direct tension strength $\sigma_{\mathrm{t}}$ & $1.7 \mathrm{MPa}$ \\
Splitting tension strength $\sigma_{\mathrm{ts}}$ & $1.9 \mathrm{MPa}$ \\
Bending strength $\sigma_{\mathrm{b}}$ & $4.0 \mathrm{MPa}$ \\
Compressive strength $\sigma_{\mathrm{c}}$ & $22.5 \mathrm{MPa}$ \\
Velocity of elastic wave $c_{0}$ & $2760 \mathrm{~m} / \mathrm{s}$ \\
\hline
\end{tabular}

Table 2 shows the static mechanical properties of the concrete specimens obtained by the static tests. Each strength is the mean value of cumulative fracture probability, which is discussed later. Here, $\mathrm{c}_{0}$ is the velocity of elastic waves, given by $\mathrm{c}_{0}{ }^{2}=\mathrm{E} / \rho$, which almost corresponded to the experimental observation of elastic waves through the concrete bar specimen.

\section{IMPACT TENSILE EXPERIMENT}

\subsection{Measurement Theory}

The space-time diagram of stress wave propagation is shown in Fig.2 to explain the present proposed measuring method. In this experimental method, the bar I is an input bar in tight contact with one end of the specimen bar II, while the bar III is a striking bar. When the striking bar III impacts collinearly the input bar I, longitudinal compressive stress waves are

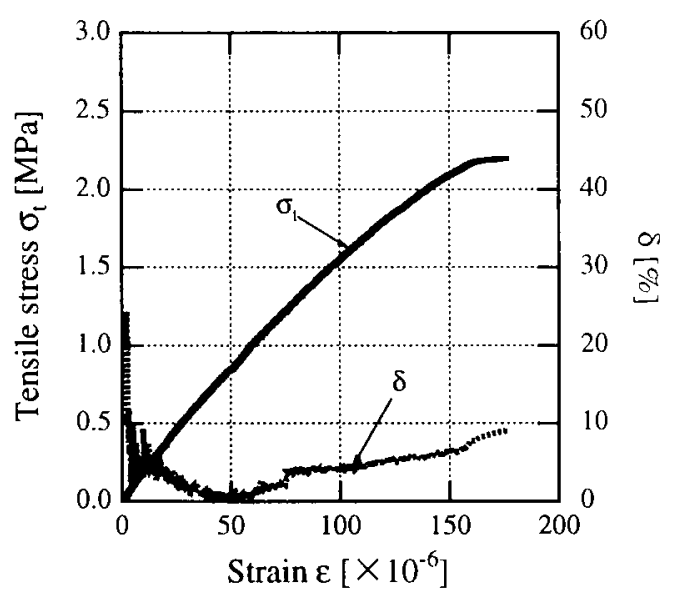

Fig.1 Direct tensile stress-strain diagram and bending component. 
propagated from the impact surface of the bar I and bar III into each bar. Now, let us consider the stress wave propagation in the input bar $I$ and the specimen bar II. A portion of the incident compressive stress wave with intensity of $\sigma$ propagated through the bar $I, \beta \sigma$, is transmitted into the bar II, and a residual portion is reflected back to the bar I as reflected tensile stress wave $\alpha \sigma$. Here, $\alpha$ and $\beta$ are the reflection and transmission factors, respectively, the details of which will be described later. In the specimen bar II, the compressive stress wave is reflected at the right free end, and the reflected tensile stress wave $\beta \sigma$ is propagated toward the left of bar II. Meanwhile, the compressive stress wave which is propagated in the striking bar III to the left is also
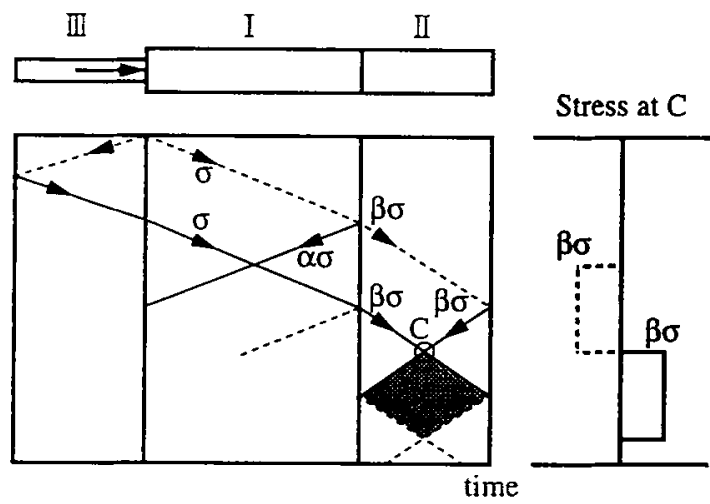

Fig.2 Concentration of tensile stress waves. reflected at the free end, and then it is transmitted into the input bar I and the specimen bar II as the tensile stress wave $\beta \sigma$. At a certain time and location in the specimen bar II, both the reflected tensile stress waves will interfere each other and give rise to a tensile stress concentration that may break the specimen bar II. The location-time of the tensile stress concentration produced in the specimen bar II is illustrated as the shadow area in Fig.2. At section $\mathrm{C}$ the tensile stress concentration appears first and has maximum duration time. Consequently, the impact tensile break in the specimen bar II is expected to occur at the section $\mathrm{C}$ or in the vicinity of $\mathrm{C}$.

\subsection{Measurement Arrangement}

An arrangement describing major components of the impact tensile test facillity is schematically shown in Fig.3. The setup consists of a compressor, a barrel, a stainless-steel striking bar, a tool-steel input bar, and a set of recording devices. The striking bar with a length of $500 \mathrm{~mm}$ and $20 \mathrm{~mm}$ diameter is chosen for this study. The input bar is of length $1500 \mathrm{~mm}$ and $50 \mathrm{~mm}$ diameter. It is adjusted to be collinearly impacted by the striking bar shot out from the air gun.Two sets of semiconductor strain gauges are cemented diametrically on the input bar for measuring incident stress waves into the specimen bar [8]. One end of a concrete specimen bar is arranged in tight contact with one end of the input bar, while the other end of the specimen bar is released from stresses. All specimens are also equipped with two strain gauges pasted diametrically at two locations, respectively, in order to measure directly stress waves propagated in the specimen bar. The response signals trapped at those locations are passed through bridge boxes to a four-channel digital oscilloscope (Nicolet, Model 400) that has capability of displaying digitized wave forms on the screen and storing them on a diskette.

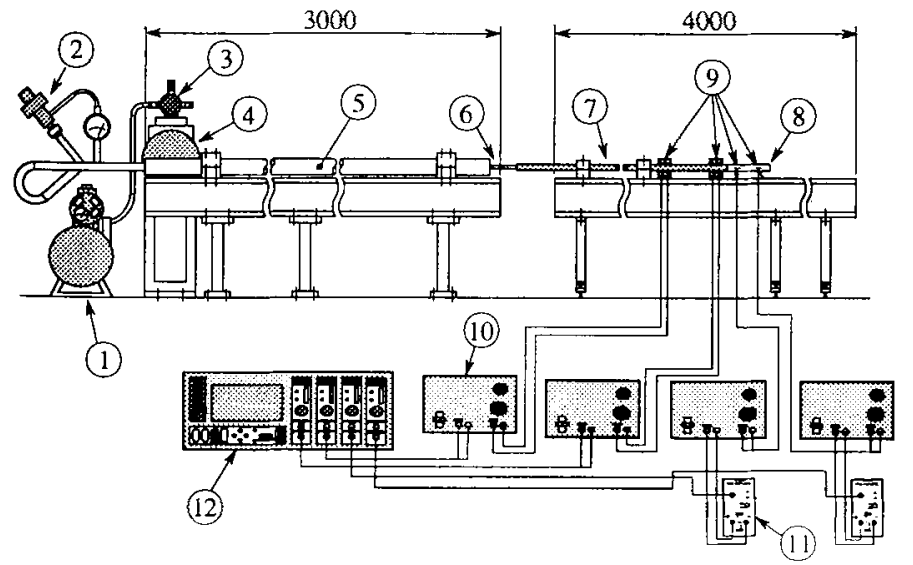
(1) Compressor
(2) Solenoid Valve
(3) Booster Regulator
(4) Air Reservoir
(5) Gun
(6) Striking Bar
(7) Input Bar
(8) Specimen
(9) Strain Gages
(10) Bridge Box
(11) Pre-Amplifier
(12) Digital Oscilloscope

Fig.3 Experimental setup for impact tensile test. 


\section{RESULTS OF IMPACT TENSILE EXPERIMENT}

\subsection{Experimental Results}

The experiments were performed under various loading conditions obtained by means of changing the air-compressor pressure and adjusting the impact distance between the input and the striking bar. The Lagrange diagram in this arrangement and the predicted stress-time diagrams at two gauge locations on the specimen bar are shown in Fig.4. The pulse duration of the incident compressive stress into the specimen bar depends on both the length and the elastic wave velocity of the striking bar. In this experiment using the $500 \mathrm{~mm}$ length stainless-steel striking bar, the duration is examined to be about $200 \mu \mathrm{sec}$. The intersection $\mathrm{C}$ of both tensile stress waves from the right and left ends of the concrete specimen bar is determined by the duration of the incident wave, the length of the concrete specimen and the stress wave velocity through it. On the other hand, the factors of reflection and transmission at the interface between the input bar and the specimen bar can be calculated in the present experiment as $\alpha=-0.73$ and $\beta=0.27$, where $1+\alpha=\beta$ on the assumption that all the incident stress, reflection stress and transmitted stress are taken to be compressive [2].

As mentioned above, in order to measure directly the behaviors of the transmitted and reflected stress waves in the specimen, strain gauges are pasted diametrically at two locations denoted by gauge locations 1 and 2 shown in Fig.4. The gauges 1 and 2 are glued at $150 \mathrm{~mm}$ and $350 \mathrm{~mm}$ from the impact end of the

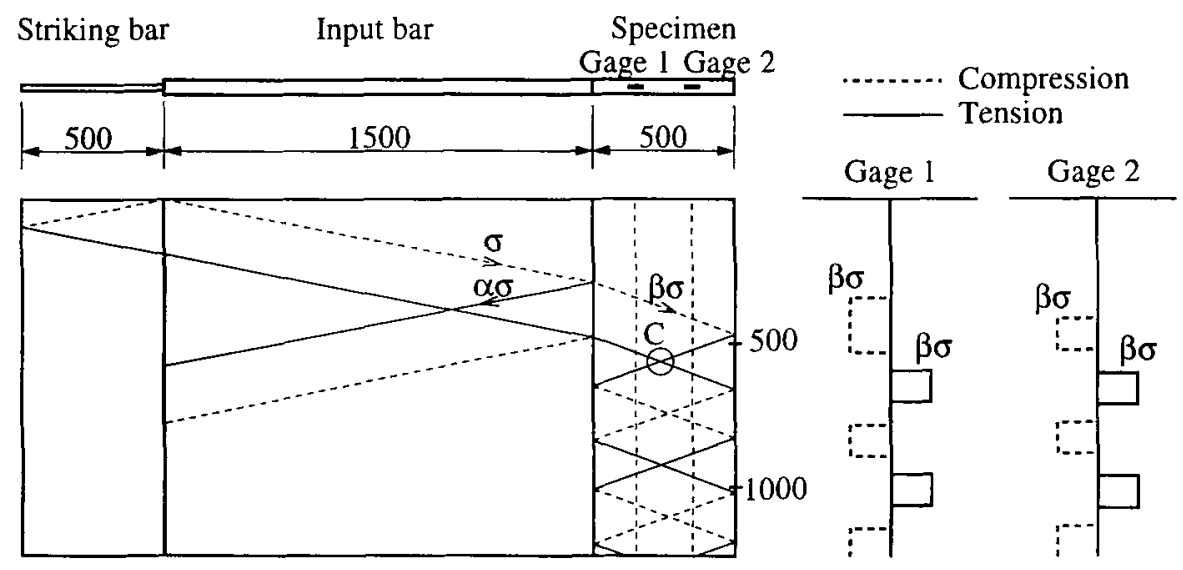

Time [ $\mu \mathrm{sec}]$

Fig.4 Space-time diagram of stress wave propagation.

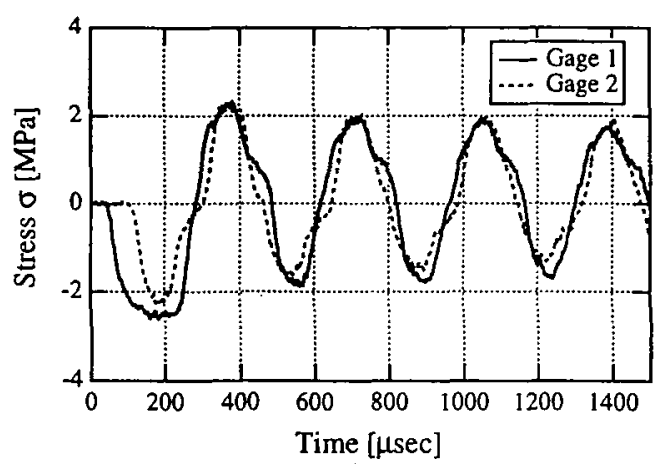

(a) Non-fracture case

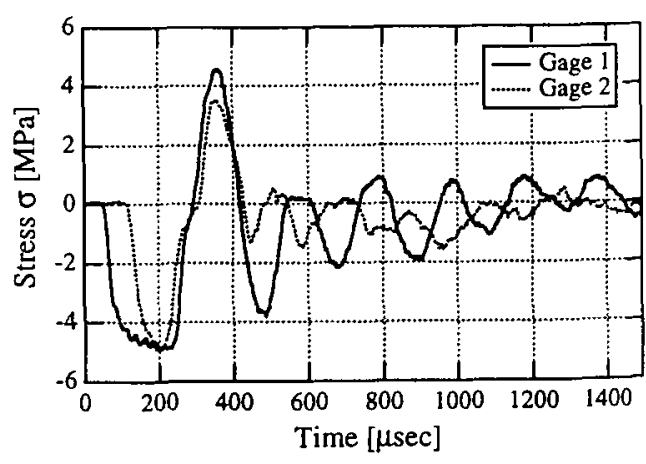

(b) Fracture case

Fig.5 Stress responses of concrete specimens. 
concrete specimen bar, respectively. Two representative configurations of the stress history observed in the impact tensile strength experiment of the concrete specimens are presented in Figs.5. The positive and negative values denote the tensile and compressive stresses, respectively. The stress response (a) corresponds to the case of no visual fracture occured in the specimen, while in the case of the stress response (b) the break of the specimen seems to be initiated at the first tensile stress concentration.

Fig. 6 shows the typical example of the impact tensile fracture of concrete specimen bars. The break position is corresponding to the predicted position $\mathrm{C}$ shown in Fig. 4 in which the tensile stress concentration was initiated in the specimen bar.

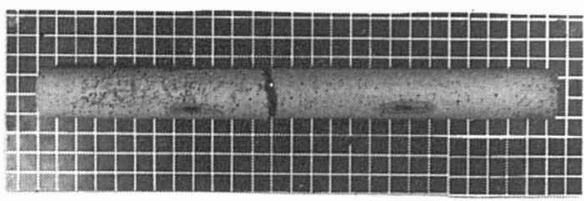

\subsection{Statistical Consideration of Experimental Data}

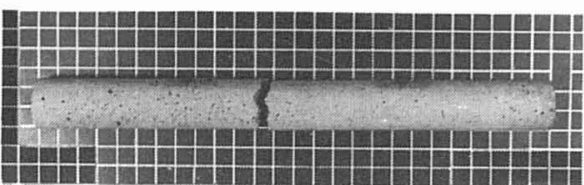

Fig.6 Photogragh of broken concrete specimens.

A suitable statistical analysis is required to treat the dispersion of the experimental data in relation to the concrete strengths. A Weibull distribution was applied to not only the impact tensile strength but also the static strengths of the concrete specimen. To plot the $i$-th ranked sample from a total of $n$ number of fractured specimens, a median-rank position was adopted, which is the distribution function $F_{i}$ expressed

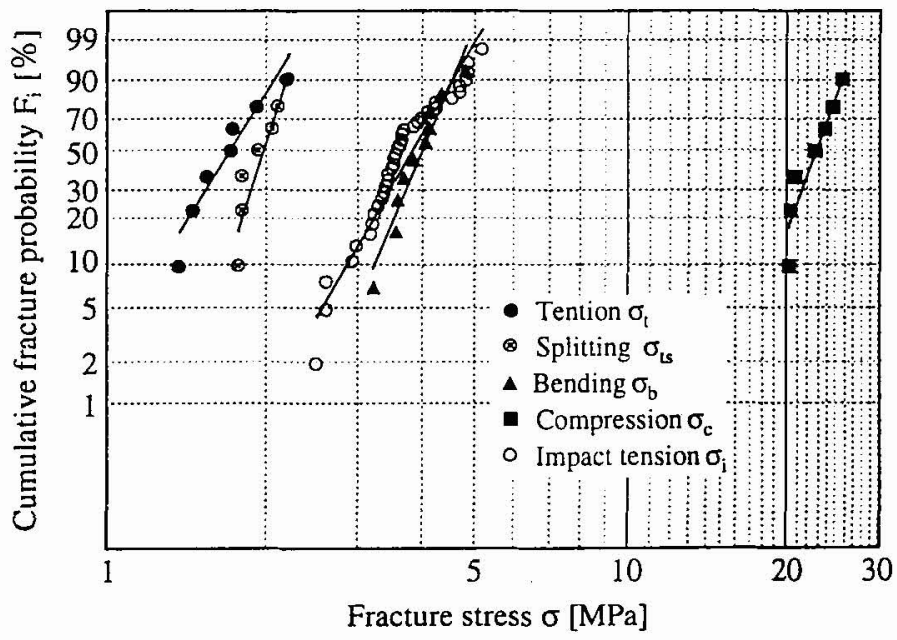

Fig.7 Weibull plots of concrete.

Table 3 Results of statistical analysis.

\begin{tabular}{|c|c|c|c|c|c|}
\hline Test & $\begin{array}{l}\text { Direct } \\
\text { tension }\end{array}$ & $\begin{array}{r}\text { Splitting } \\
\text { tension }\end{array}$ & $\begin{array}{c}\text { Impact } \\
\text { tension }\end{array}$ & Bending & Compression \\
\hline $\begin{array}{l}\text { Number of } \\
\text { samples } n\end{array}$ & 7 & 7 & 36 & 10 & 7 \\
\hline $\begin{array}{c}\text { Shape parameter } \\
m\end{array}$ & 6.25 & 11.4 & 6.32 & 9.27 & 10.7 \\
\hline $\begin{array}{c}\text { Scale parameter } \\
\xi[\mathrm{MPa}]\end{array}$ & 1.82 & 2.04 & 3.99 & 4.14 & 23.5 \\
\hline Mean $\mu[\mathrm{MPa}]$ & 1.70 & 1.96 & 3.72 & 3.95 & 22.5 \\
\hline $\begin{array}{c}\text { Standard deviation } \\
\text { s.d. [MPa] }\end{array}$ & 0.32 & 0.21 & 0.69 & 0.26 & 2.10 \\
\hline
\end{tabular}


approximately in terms of $F_{i}=(i-0.3) /(n+0.4)$. The data plotted on the Weibull probability paper, i.e.. $\ln \ln \left[1 /\left(1-F_{i}\right)\right]$ versus $\ln (\sigma)$ lied on straight lines, as shown in Fig. 7 . The straight lines are drawn by meitls of the method of least squares. The Weibull modulus (shape parameter) $m$ of each plot and the scate parameter $\xi$ (fracture probability $63.2 \%$ ) can be found from the Weibull distribution. The mean stress $\mu$ and the standard deviation s.d. can be calculated based on such data. The statistical results of the concrete used for this study are shown in Table 3. Comparing the impact tensile strength with the static tensile strengths, it is worth noting that the impact tensile strength of the concrete is significantly influenced and increased by the loading rate conditions.

\section{CONCLUSIONS}

In this paper, a newly developed measuring method for impact tensile strength of brittle materials has been proposed. The method is based on the superposition and concentration of tensile stress waves reflected both from the free ends of a striking bar and a specimen bar. The experiment is conducted by means of the Hopkinson-bar technique. The impact tensile experiment of concrete specimen bars was perfomed as well as static strength tests of direct tension, spliting tension, bending, and compression. The fracture position in the concrete specimen bar corresponded to the predicted position in which tensile stress concentration is initiated. The impact tensile strength of the concrete for this investigation is significanily influenced by thi loading rate. and it is found to be approximately twice the static values.

\section{ACKNOWLEDGEMENT}

This research was performed as a joint research project between Muroran Institute of Technology and the Disaster Prevention Research Institute of Kyoto University. The authors would like to express their appreciation to the Disaster Prevention Research Institute for partial financial support.

\section{REFERENCES}

[1] Goldsmith. W., Impact, Edward Arnold. London, 1960.

[2] Johnson, W., Impact Strength of Materials, Edward Arnold, London, 1972.

[3] Nonaka, T., Clifton, R. and Okazaki, T., "Longitudinai Elastic Waves in Columns due to Earthquake Motion", Int. J. Impact Engng, Vol.18, Nos.7-8. 1996, pp.889-898.

[4] Birkimer, D.L and Lindemann, R., "Dynamic Tensile Strength of Concrete Materials", J. American Concrete Institute, Vol. 68, 1971, pp.47-49.

[5] Griner, G.R., Sierakowski, R.L. and Ross, C.A., "Dynamic Properties of Concrete under Impact Loading", Shock Vib. Bull., Vol.45, No.4, 1975, pp.131-142.

[6] Ross, C.A., Kuennen, S.T. and Tedesco, J.W., "Experimental and Numerical Analysis of High Strain-Rate Concrete Tensile Tests". Micromechanics of Failure of Quasi-Brittle Materials (eds. S.P. Shah, S.E. Swartz and M.L. Wang), 1990, pp.353-363, Elsevier Applied Science.

[7] Japan Concrete Institute, Handbook of Concrete (2nd ed.), Gihoudo, 1996.

[8] Daimaruya, M, Kobayashi, H. and Bustami, S., "Fracture Initiation and Development in Plaster Plates under Impacts", DYMAT Journal, Vol. 1, No.4, 1994, pp.289-305.

[9] Daimaruya, M., Kobayashi, H., Bustami, S. and Chiba, M., "A Measuring Mehod for Impacl Tensile Strength of Brittle Materials", J. Soc. Mat. Sci., Japan, Vol.45, No.7, 1996, pp.823-828.

[10] Daimaruya, M. and Bustami, S., "Concentration of Tensile Stress Waves and Impact Tensile Strength of Brittle Materials", Proc. APCFS'96, July, 1996, Kyongiu, Korea, pp.709-714. 